\title{
Analysis of Failures of Fixed Plate on Closing Mechanism of High Pressure Press
}

\author{
František Trebuňa ${ }^{1}$, František Šimčák ${ }^{1}$, Jozef Bocko ${ }^{1}$ and Miroslav Pástor ${ }^{1 *}$ \\ 1* Faculty of Mechanical Engineering, Technical University of Košice, Department of Applied Mechanics and mechanical Engineering, Letná 9, 04200 \\ Košice
}

\begin{abstract}
In the paper are presented results of failure analysis of fixed plate on closing mechanism of press for high pressure die casting of products made of aluminium alloy. On the basis of analysis of operation conditions of press as well as material of damaged fixed plate and their stress analysis by FEM for various loading cases, the conclusions were formulated about possible causes of plate failure.
\end{abstract}

Keywords: press, fixed plate, fracture failure, finite element method.

\section{Introduction}

High pressure die casting is used for production of castings of complex shapes with high quality of surface, while very good exploitation of melted metal is ensured. Large amount of production is oriented to high pressure die casting of aluminium alloys (Fig. 1), especially for automotive industry.

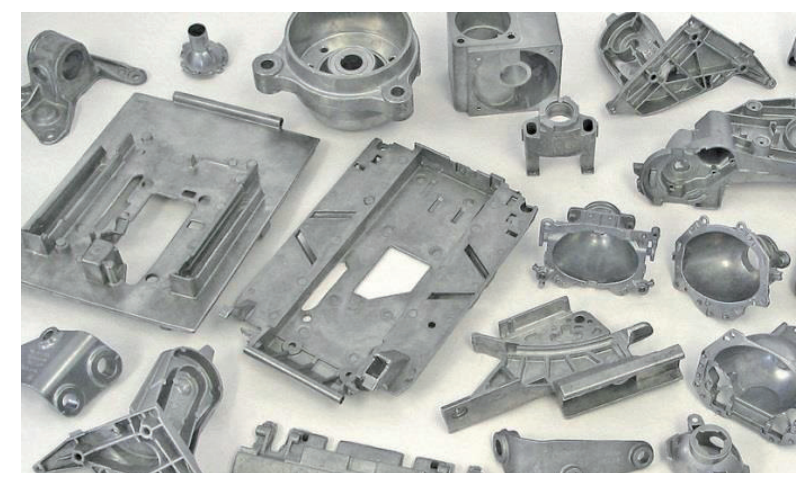

Fig. 1: Aluminium alloy castings produced by high pressure die casting [1].

The castings are produced on presses (Fig. 2) using the process in which the melted metal is injected into metal die, where after solidification casting according to die shape is created.

The equipment that serve for the production of machine parts by pressing and casting are loaded by repeating forces which often cause crack initiation in locations of stress concentrators [2, 3]. In the paper is given analysis of failure of fixed plate on closing mechanism of press which occurred after approximately 14 years of press operation.

\section{Concise description of press operation and locations of failure}

One part of high pressure die connected with casting system is mounted to fixed plate (Fig. 3). The second part of casting die is mounted to moveable plate (Fig. 3). Before casting, the both parts of die are joined, so the die is closed and prepared for 


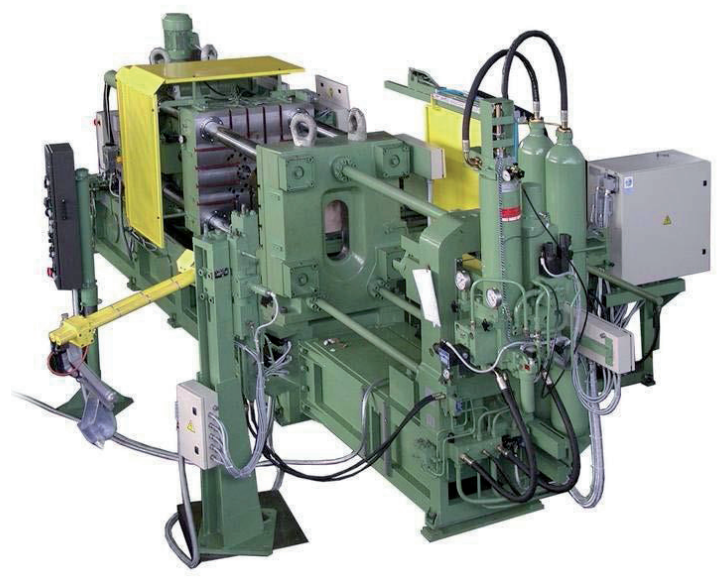

Fig. 2: Press machine for high pressure die casting [1].

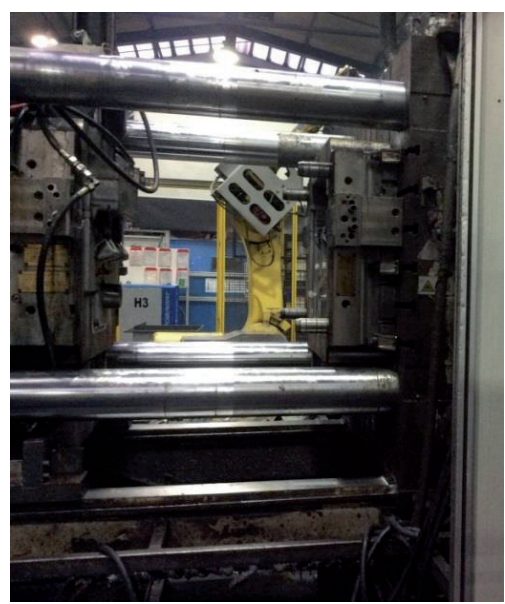

Fig. 3: View to the fixed (right) and movable (left) part of casting die.

casting. Then, into cavity of closed die, the melted metal is injected, creating after solidification the casting of prescribed shape. In Fig. 3 is a view to the working area of casting machine with fixed and moveable parts of casting die.

The moving plate is sliding on two leading rails and four leading columns (Fig. 3). On the columns is mounted fixed plate with the shape according to Figs. 4 and 5.

The fixed plate is mounted on leading columns by nut and attachment screws. The press was in operation since 2001, while in 2015 the crack was detected on fixed plate of the machine (Fig. 6).

The crack is located on outer side of fixed plate, see Fig. 6.
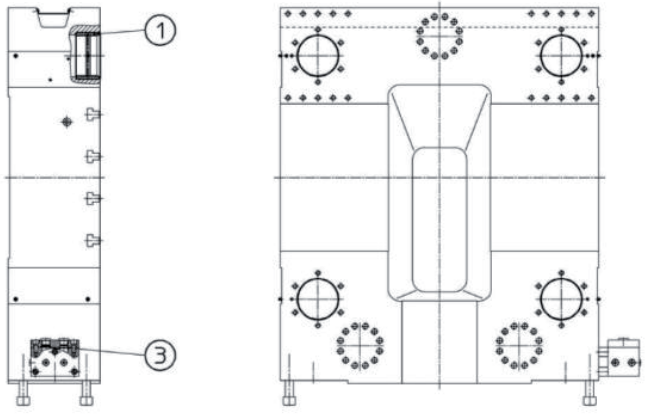

Fig. 4: Drawing of fixed plate.

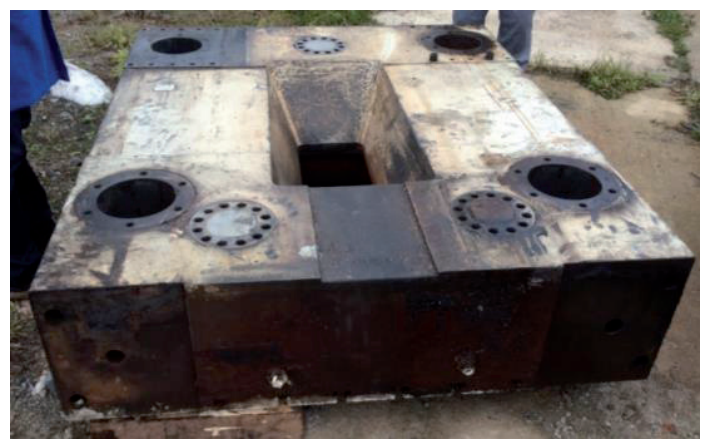

Fig. 5: View to the analyzed fixed plate.

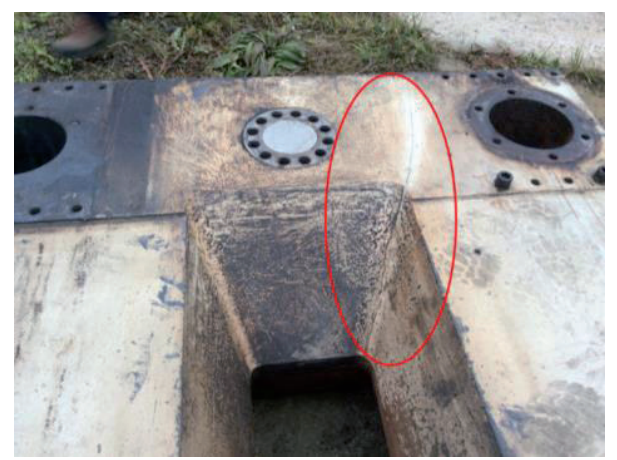

Fig. 6: Fixed plate with crack.

\section{Verification of mechanical properties of material of fixed plate}

According to data gained from operator, the fixed plate was made of ferritic-perlitic nodular cast iron STN 422305 with mechanical properties $R_{p 0,2} \geq 320 \mathrm{MPa}, R_{m} \geq 500 \mathrm{MPa}, A_{5} \geq 7 \%$, $H B=170-240, E=169 \mathrm{GPa}, G=65 \mathrm{GPa}$. The yield point of material under temperature $100^{\circ} \mathrm{C}$ is $R_{p 0,2} \geq 305 \mathrm{MPa}$.

As there was problem to provide mechanical tests of material by tensile tests, the approximate 
assessment of material properties has been accomplished by hardness test with POLDI hammer [4].

As there was problem to provide mechanical tests of material by tensile tests, the approximate assessment of material properties has been accomplished by hardness test with POLDI hammer [4].

The hardness was determined in four selected areas of fixed plate - I, II, III and IV. The areas I and II were selected on the side of mounting of casting die (Fig. 7) and the areas III and IV on outer side of fixed plate (Fig. 8).

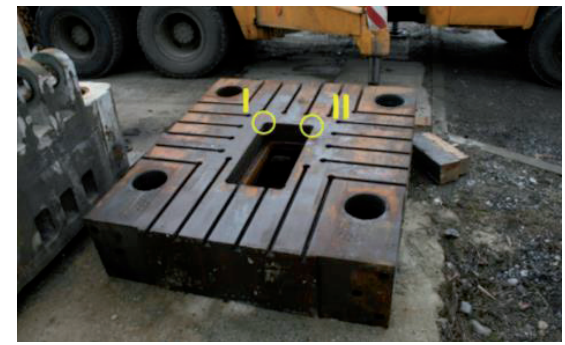

Fig. 7: Locations of hardness measurement from the side of die fixation (I and II).

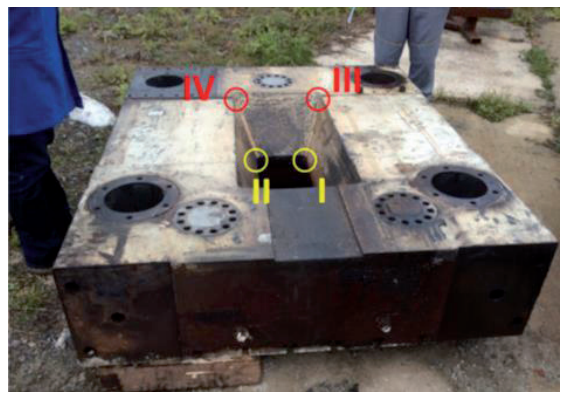

Fig. 8: Locations of hardness measurement from outer side (III and IV).

The locations of hardness measurements in the area III (crack vicinity) are documented on Fig. 9 (locations No. 1 to No. 12). Average values of hardness determined from at least 7 measurements in individual areas are given in Tab. 1.

The measured values lie in prescribed interval of hardness $H B=170$ - 240 for material declared by producer. From the measured values results that the hardness on both sides of fixed plate shows slight differences. In areas I and III is hardness $H B=216$ and 209 , respectively, in areas II and IV is hardness $H B=190$ and 202 , respectively.

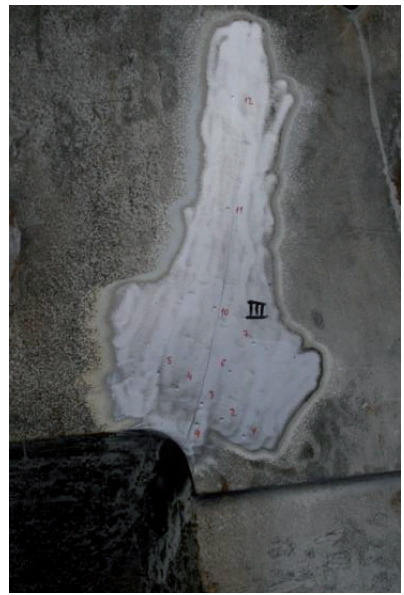

Fig. 9: Locations of hardness measurement in the area III (crack vicinity).

Table 1: Average values of measured hardness.

\begin{tabular}{|l|l|l|l|l|}
\hline & \multicolumn{5}{c|}{ Locations of measurement } \\
\hline & | & \multicolumn{1}{|c|}{ II } & II & IV \\
\hline Average values of hardness HB & 216 & 190 & 209 & 202 \\
\hline
\end{tabular}

\section{Stress analysis of fixed plate of closing mechanism by the finite element method}

The stress analysis of fixed plate was realized by using numerical modelling by the finite element method $[5,6,7]$. Two cases of force transmission by leading columns has been modelled. In the first one, all four leading columns transmitted the same part of adhering force $9300 \mathrm{kN}$ acting on casting die mounted to fixed part of casting press. The boundary conditions for this case are shown in Fig. 10a. On the basis of information from operator we know that the column have different temperatures during casting process. Accordingly, the second model simulate fact that one of the columns has higher temperature by $10^{\circ} \mathrm{C}$ than the others, see Fig. 10b.

The computation was accomplished for four cases of force transmission from casting die to fixed plate, determined by dimensions of casting die. In Fig. 11 is a model of fixed plate with casting die $700 \times 700 \mathrm{~mm}$. In Fig. 12 is given field of equivalent stresses for the case of uniform loading of leading columns and in Fig. 13 is given field of equivalent stresses for the case of non-uniform loading of leading columns one column has higher temperature by $10^{\circ} \mathrm{C}$ than the others. 


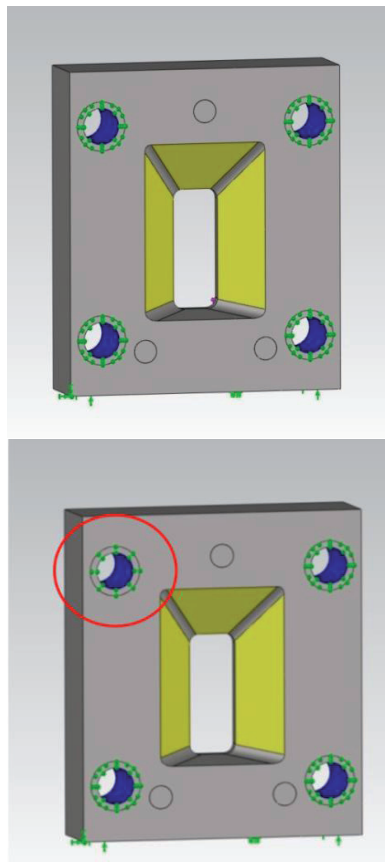

(a)

(b)

Fig. 10: Model of fixed plate with boundary conditions a) uniformly distributed force transmission by individual columns, b) non-uniformly distributed force transmission by individual columns, temperature influence to one leading column (marked).

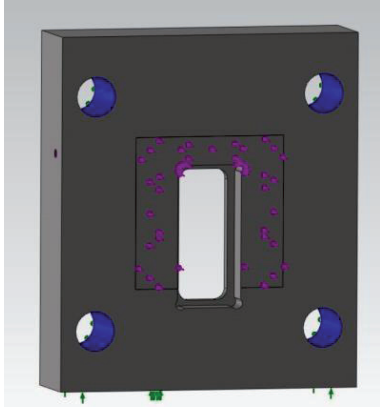

Fig. 11: Boundary conditions for die dimensions $700 \times 700 \mathrm{~mm}$.

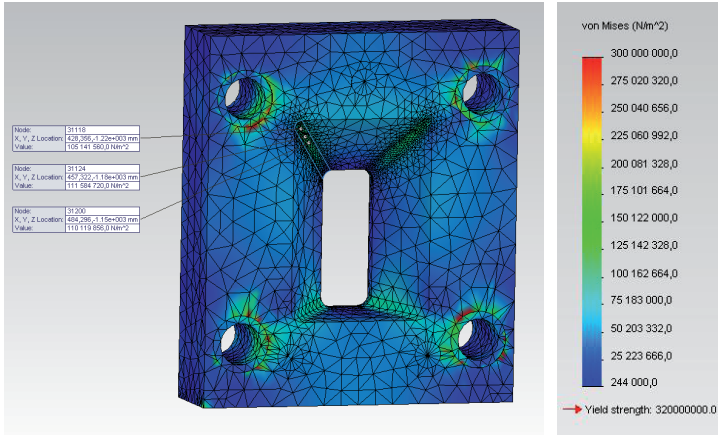

Fig. 12: Field of equivalent stresses for uniform force transmission by individual leading columns.

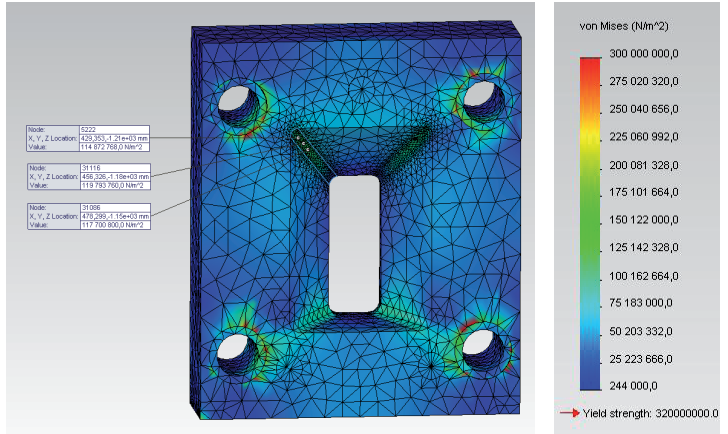

Fig. 13: Field of equivalent stresses for non-uniform force transmission by individual leading columns - temperature influence to one leading column.

In Fig. $14 \mathrm{a}, \mathrm{b}$ are given boundary conditions for models of fixed plate used with casting dies of different dimensions. In Fig. $14 \mathrm{C}$ is a model of fixed plate with casting die $1100 \times 750 \mathrm{~mm}$, but the contact area is deformed due to loading by casting die with dimensions $800 \times 1000 \mathrm{~mm}$ and accordingly the loading acts only on top and bottom part of plate.

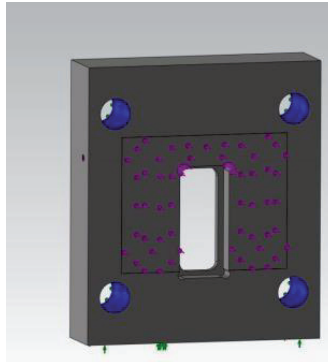

(a)

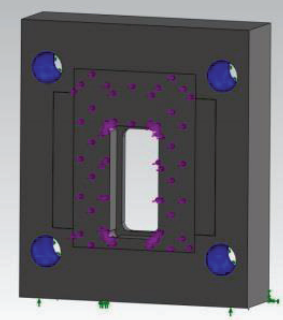

(b)

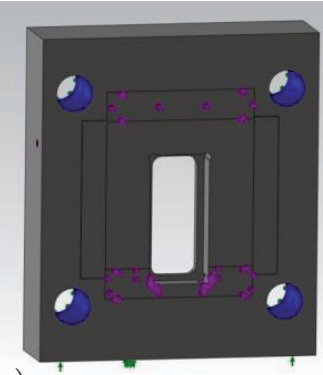

(c)

Fig. 14: Boundary conditions for die dimensions a) $800 \times 1000 \mathrm{~mm}$, b) $1100 \times 750 \mathrm{~mm}$, c) $1100 \times 750 \mathrm{~mm}$ - deformed area on fixed plate. 
Table 2: Magnitudes of maximum stresses in location of crack.

\begin{tabular}{|c|c|c|c|c|}
\hline \multirow[b]{2}{*}{ Boundary conditions } & \multicolumn{4}{|c|}{ Variant (according to used form) } \\
\hline & $\begin{array}{c}I \\
(700 \times 700 \mathrm{~mm})\end{array}$ & $\begin{array}{c}\text { II } \\
(800 \times 1000 \mathrm{~mm})\end{array}$ & $\begin{array}{c}\text { III } \\
(1100 \times 750 \mathrm{~mm})\end{array}$ & $\begin{array}{c}\text { IV } \\
(1100 \times 750 \mathrm{~mm})\end{array}$ \\
\hline Uniform loading of all four leading columns & $111 \mathrm{MPa}$ & $82 \mathrm{MPa}$ & $91 \mathrm{MPa}$ & $64 \mathrm{MPa}$ \\
\hline $\begin{array}{l}\text { Non-uniform loading of all four leading columns } \\
\text { - increased temperature in one leading column } \\
\text { by } 10^{\circ} \mathrm{C}\end{array}$ & $120 \mathrm{MPa}$ & $92 \mathrm{MPa}$ & $103 \mathrm{MPa}$ & $74 \mathrm{MPa}$ \\
\hline
\end{tabular}

In Tab. 2 are given values of maximal stresses in location of crack, gained by numerical modelling under various operation regimes.

Tab. 2 shows that the stress in fixed plate is inappropriately influenced also by non-proportional heating of leading columns. From the analysis results that heating of one column by approximately $10^{\circ} \mathrm{C}$ increases the levels of maximal stresses by $10-15 \%$.

\section{Life time assessment of fixed plate from the point of view of fatigue loading during operation}

The fixed plate of closing mechanism was loaded during operation of casting press by vanishing loading with maximal adhering force $\mathrm{F}=9300 \mathrm{kN}$. The adhering force is transmitted to the fixed plate by surface of casting die. The stress analysis of fixed plate was described in previous section of the paper. As was given above, the fixed plate is made of ferritic-perlitic nodular cast iron STN 422305 with mechanical properties $R_{e} \geq 320 \mathrm{MPa}, R_{m} \geq 500 \mathrm{MPa}$ [8].

Taking into account vanishing bending loading of fixed plate, the fatigue limit of material of fixed plate is $\sigma_{h C o}=0,74 \cdot \mathrm{Rm}=0,74 \cdot 500=370 \mathrm{MPa}$ [9].

The real fatigue limit of fixed plate in location of crack initiation is determined from relation

$$
\sigma_{h C_{0}}^{*}=\sigma_{h C_{o}} \cdot \frac{1}{\beta_{0}} \cdot v_{0} \cdot \eta_{p},
$$

where: $\beta_{0}=1+\eta_{c} \cdot(\alpha-1)$ is a notch coefficient, $\alpha$ - shape coefficient, $\eta_{c}=R_{e} / R_{m}$ - coefficient of notch sensitivity, $v_{0}$ - coefficient of size for bending, $\eta_{p}$-coefficient of surface quality.

Using of diagrams 15.077 to 15.080 [9] of shape coefficients we get $\alpha=4,80$. For the given material quality and dimensions of fixed plate we consider $v_{0}=1,24$, while the coefficient of surface quality for the casted machine part is chosen to be $\eta_{p}=0,65$.
The real fatigue limit is then

$\sigma_{h C_{o}}^{*}=370 \cdot \frac{1}{3,432} \cdot 1,24 \cdot 0,65 \doteq 87 \mathrm{MPa}$

while $\eta_{c}=\frac{370}{500}=0,64$,

$\beta_{0}=1+0,64 \cdot(4,8-1)=3,432$.

Comparison of extremal values of stresses in Tab. 2 and magnitude of fixed plate fatigue limit in location of crack leads to conclusions concerning of possible reasons of crack initiation in fixed plate.

\section{Conclusion}

Realized analysis leads to the following conclusions:

- The measured hardness HB corresponds to the interval given in material description of fixed plate (170-240).

- The loading of the plate is influenced by position and shape of contact area between die and fixed plate.

- The analyses of various load cases results to statement that the most inappropriate loading occurs for die with minimal dimensions (700 x $700 \mathrm{~mm}$ variant I according to Tab. 2). However, according to the operator, this die was not used in this casting machine.

- Assessment of different variants (II and III - Tab.2) shows that the most inappropriate loading case is variant III, under which the failure of fixed plate occurred (crack initiation).

- The analysis leads to statement that the number of cycles to failure exclusively for variant III is $1.776 .10^{6}$.

- From the data of operator results that the casting press realized $3.10^{6}$ loading cycles. The majority of working cycles were realized for variant II. However, this could not lead to the failure. After some unspecified number of those cycles the press operates under 
variant III, summation of damage accumulation for variant II and III lead to crack initiation.

- The stress in fixed plate is inappropriately influenced by non-proportional heating of leading columns. From the numerical analysis results that difference in temperature by approximately $10^{\circ} \mathrm{C}$ with respect to the others columns increases the levels of maximal stresses in fixed plate by approximately 10 - 15\%, which lead to further decreasing of cycles number to failure.

\section{Acknowledgements}

This paper was supported by the projects of the Slovak Grant Agency, VEGA No. 1/0393/14and No. 1/0751/16.

\section{References and Notes}

[1] https://www.google.sk/search?q=odlievan\%C3\%A9+vy robky+zo+zliatin+hlinika\&client=firefox-b\&source $=$ Inms \&tbm=isch\&sa=X\&ved=0ahUKEwjckuTWotTMAhWIC50 KHfUdCHUQ_AUIBygB\&biw=1920\&bih=920\#imgrc $=$ WNBTQLFS1RSPM\%3A

[2] Trebuña, F., et al. Analysis of crack initiation in the press frame and innovation of the frame to ensure its further operation. Engineering Failure Analysis, Vol. 18, 1, 2011, pp. 244-255.

[3] Zheng, S. et al. Failure analysis of frame crack on a widebody mining dump truck. In: Engineering Failure Analysis Vol. 48 (2015), p. 153-165, ISSN 1350-6307

[4] Trebuňa, F. - Šimčák, F. Odolnost’ prvkov mechanických sústav. EMILENA, Košice, 2004

[5] Écsi L. - Élesztös P. Moving toward a more realistic material model of a ductile material with failure mode transition. In: Materialwissenschaft und Werkstofftechnik. Vol. 43, No. 5 , 2012, pp. 379-387

[6] Jančo R. FEM Approach of Solution of Beams on Elastic Foundation. In. Applied Mechanics 2011, 13 th Conference Proceeding, Brno, Academy of Science of the Czech Republic, pp. 71-74

[7] Shang, X., Zhou, J., Zhuo, F., Luo, Y. Analysis of crack for complex structural parts and simulation optimization during hot forming. International Journal of Advanced Manufacturing Technology. Vol. 80, Issue 1-4, 2015, pp. 373-382

[8] Fürbacher, l., et al. Lexikon technických materiálů. Svazek 1, Verlab Dashőfer, 2005.

[9] Trebuňa, F. - Šimčák, F. Príručka experimentálnej mechaniky. Typopress, Košice, 2007

\section{Biographical notes}

František Trebuňa, Dr.h.c., mult., prof., Ing., CSc., (1947) is a professor of Applied mechanics, Dean of the Faculty of Mechanical Engineering of Technical university of Košice. He is author of 14 monographs, 13 university textbook, special book publications, 12 university notebooks and more than 350 publications in journals and conference proceedings in Slovakia and abroad. He is also author of important projects and engineering works. His professional and scientific orientation is oriented to experimental and numerical methods of mechanics, prediction lifetime of structure, stress and strain analysis, photoelasticimetry, redistribution of stresses, modal analysis. He received several prizes at home and abroad. He received three honorary Doctor Honoris (ausa (Dr.h.c.) including two from foreign universities for the development of applied mechanics and mechatronics and last year he received Honorary Doctorate of Letters (For the extraordinary contribution in the area of creation, development and publication activity in the scientific branches of applied mechanics and mechatronics), IBC Cambridge, England. At the beginning of 2014 he received State prize he got "Honour of Ludovit Šturr of the 2nd order". Prof. Trebuña is a member of several Scientific councils on technical universities in Slovakia and abroad and member of editorial boards of journals.

František Šimčák, prof., Ing., CSc., (1947) is a professor of Applied mechanics, Head of the Department of Applied Mechanics and Mechatronics. He is author of 10 monographs, 11 university textbook, 6 university notebooks and more than 250 publications in journals and conference proceedings in Slovakia and abroad. He is co-author of important projects and engineering works. He received several prizes due to his scientific results. His professional and scientific orientation is oriented to strength and stiffness analysis of thin-walled elements and structures, computational and experimental stress analysis of structural elements made of classical and composite materials, plastic properties of steel sheets and lifetime of structures. He is a member of Scientific council of the Faculty of Mechanical Engineering, Technical University of Košice.

Jozef Bocko, prof., Ing., CSc., (1959) is a professor of applied mechanics. He is author of 2 monographs, 11 university textbook and more than 200 publications in journals and conference proceedings in Slovakia and abroad. He is author and co-author of important projects and engineering works. His professional and scientific interests are oriented to the finite element method, nonlinear mechanics, shell theory, application of Lie groups in mechanics. He is a member of Scientific council of the Faculty of Mechanical Engineering, Technical University of Košice and member of council of Slovak Association of Mechanics by Slovak Academy of Sciences.

Miroslav Pástor, doc. Ing., PhD., (1975) is a associated professor on the Department of Applied Mechanics and Mechatronics. In 2008 he received PhD. in the field of Applied mechanics. In 2013 he habilitated in the area of Applied mechanics. He is author of 3 monographs, 4 university textbook and more than 70 publications in journals and conference proceedings at Slovakia and abroad. He is co-author of important projects and engineering works. He made remarkable work on the building of laboratories and on publication of monographs and university textbook at the department. His professional and scientific orientation is oriented to experimental of mechanics, prediction lifetime of structure, stress and strain analysis, photoelasticimetry. He is a member of Slovak Association of Mechanics by Slovak Academy of Sciences. 